\title{
External debt sustainability in the transition economies of southeast Europe: an application by wavelet-based unit root tests
}

\author{
Memduh Alper DEMIR*
}

\begin{abstract}
This study aims to examine the external debt sustainability in the transition economies of Southeast Europe, some of which are among the developing countries, by wavelet-based unit root tests. In this framework, the unit root test was applied to the gross foreign debt variable, and the variable consisting of the ratio of the gross foreign debt to the gross domestic product (GDP) of the countries and their stationaries were examined. Each country differs depending on the time dimension in the analysis. However, in general, starting from the 2000s until the second quarter of 2020, the data were taken as a quarter. The data were first tested for linearity and the FWKSS and WKSS unit root tests were applied to the nonlinear data. According to the test results, external debt is sustainable in Romania and Bulgaria for both variables in the analysis. However, it has been observed that foreign debt is unsustainable in North Macedonia and Slovenia for these two variables. In terms of the gross external debt variable, external debt was sustainable in Albania and Croatia. However, in terms of gross external debt/GDP ratio, it has been found that foreign debts are unsustainable in Albania and Croatia.
\end{abstract}

Keywords: Southeast Europe, transition economies, external debt, sustainability, wavelet-based unit root tests, FWKSS, WKSS

\section{Introduction}

External debt sustainability is an important issue in economic policy. It is observed that especially developing countries borrow foreign debt to meet their increasing current account deficit, to finance their investments, and to ensure their economic growth. In the case of insufficient domestic debt resources, foreign debt is taken. According to the World Bank, "total external debt" is defined as the sum of

\footnotetext{
* Memduh Alper DEMIR is PhD at the Kastamonu University, Kastamonu, Turkey; e-mail: mademir@kastamonu.edu.tr.
} 
public debt and publicly guaranteed long-term debt, non-private guaranteed longterm debt, IMF loans and short-term debt (World Bank, 2011).

Unlike concepts such as optimality, feasibility, equilibrium, steady-state, and stability, 'sustainability' does not have a clear mathematical equivalent in the economics literature. Therefore, it is very difficult to define the concept of sustainability. However, the concept of sustainability can be explained by considering the extreme values that economic variables can take. In an economic problem, infeasible values of variables are those which cannot be attained, because they are simply not possible, or because the penalties for attaining them are prohibitively high. Thus, the level of the capital stock cannot be less than zero, the output level is limited to a maximum feasible quantity above, and while consumers may be zero, death is the consequence. Unsustainable economic conditions can be regarded as situations that would ultimately lead to the values of variables at the margin of the feasible set, especially without debt-related policy and other external changes. All the other paths are, then, sustainable. In many cases, unsustainable paths will have some element of instability, though, as noted, this is not sufficient to make them unsustainable (Pitchford, 1995).

Although there is no generally accepted and clear definition of external debt sustainability, it may be regarded as the willingness and ability of a country to pay off all its current and future debts - because debts can be kept as long as they are paid. In other words, sustainability is the ability of the country to fulfill its foreign obligations (Krugman, 1988).

The purpose of external debt sustainability analysis is to assess a country's capacity to finance policy objectives and serve the ensuing debt. Therefore, external debt applies to debt obligations owed by residents (both public and private sectors) in the economy to non-residents for external debt sustainability analyses. In growing economies, foreign financial resources may be required to supplement domestic savings to finance investment. However, the introduction of external finance can also lead to the accumulation of unsustainable external debt, which is expensive for a country and can interfere with the smooth functioning of international capital markets. The sustainability analysis of external debt aims to help policymakers identify imbalances (IMF, 2014).

In this context, external debt sustainability in the transition economies of Southeast Europe, some of which are among the developing countries, is examined by using wavelet-based unit root analysis. In the next part of the study, a brief literature review, revealing the studies examining external debt sustainability of the transition economies of Southeast Europe, is carried out. While the theoretical background of debt sustainability based on the analysis of inter-temporal budget constraints is given in the third part of the study, the econometric methodology of the study is presented in the fourth chapter, and the data set and empirical findings are presented in the fifth chapter. The study is completed with the conclusion section. 


\section{Literature Review}

There are many studies in the literature about external debt sustainability. However, in our study, an analysis of external debt sustainability has been carried out only in some of the countries of Southeast Europe. Therefore, the literature review has been limited to these countries. These countries are Albania, Bulgaria, Croatia, North Macedonia, Romania, and Slovenia.

Andonova and Stefanova (2015) stated in their studies using VAR analysis that Macedonia's external debt is sustainable in the medium term. The analysis period is between $1998 \mathrm{q} 1$ and $2013 \mathrm{q} 4$.

Jošić (2013) descriptively analyzed the debt status of Croatia and Southeast European countries in 2010 by taking into account some debt ratios. In Croatia and Serbia, the variables of total external debt to GDP ratio, the ratio of total external debt to exports, and the ratio of total external debt service to exports were unsustainable. The variables for the ratio of net financial transfers to imports and net financial transfers to GDP have turned out to be unsustainable in Albania and Moldova. According to the results of the analysis, the total external debt to GDP ratio in Bulgaria; the ratio of total external debt service to exports in Romania and Turkey were unsustainable. We found there was no problem in external debt indicators in Bosnia-Herzegovina and North Macedonia.

Vlahinić-Dizdarević et al. (2006) studied external debt in Southeast European countries for the period 1999-2004. They stated that the increase in external debt in Croatia and Romania threatens the sustainability of macroeconomic stability. In terms of the ratio of international reserves to external debt, the lowest scores are in Serbia, Montenegro, and Croatia. However, this indicates that it may be vulnerable to future liquidity risks. While the ratio of debt to GDP decreased in Albania, BosniaHerzegovina, and Bulgaria, there was an increase in Croatia. Also, considering the variable of debt-to-export ratio, Croatia had the highest ratio among the aforementioned countries. In terms of the ratio of debt service to exports, the highest rates were recorded in Bulgaria, Croatia, and Romania in 2004. The authors did not reach the unsustainable phenomenon in this descriptive study. However, they stated the existence of threats.

Emilia and Emilian (2008) examined the sustainability of public and external debt in their work by using the co-integration method for the period January-1992 and December 2007 for Romania. According to the results of the study, the debt in Romania was in a weak and sustainable form.

In their descriptive studies, Toskovic et al. (2016) examined the extent of the increasing trend of external debt in the Western Balkan countries, Albania, BosniaHerzegovina, North Macedonia, Montenegro, and Serbia, for the period 2004-2014. Serbia had the highest debt level in the period under review, while Bosnia and Herzegovina had the second and Montenegro the lowest. In the study, which did not contain a definite statement about sustainability for all countries in the analysis, a 
high increase in external debt was recorded in 2008 - the year of the global financial crisis.

Pivac and Pečarić (2010) examined external indebtedness trends in ten selected countries in transition economies by using multivariate cluster analysis. They showed that the situation of Southeast European countries was not better compared to the Central European countries.

In his descriptive study, Gligorov (2004) showed that the current debt accumulation trend was unsustainable in Croatia. Especially in his study for the period of 1994-2003, he stated that the ratio of debt to GDP and exports increased from 1999 to 2003 . He stated that if high growth rates are achieved in the economy and there are no negative external shocks, sustainability can be achieved.

Cuestas et al. (2015) analyzed the variables of net foreign debt / GDP and international investment position / GDP for different European countries from the early 2000 s to $2013 \mathrm{q} 3$ by using the Bai-Perron test, one of the structural breakage tests. Unsustainability was found in Southeast European countries such as Bulgaria, Romania, and Slovenia.

Man et al. (2015) descriptively analyzed the internal and external debt of the people in Romania from 2001 to 2010. As a result, they stated that for the sustainability of both internal and external public debts, the macroeconomic indicators of the country should be improved and the pressures of international financial institutions should be well managed.

Enache (2010) stated in her statistical study for Romania that the increase in current account deficits from 2009 to 2010 will also affect the increase in external debt and negatively affect sustainability.

Babić et al. (2004) analyzed the external debt sustainability in Croatia for the period 1997-2007 descriptively. While determining that the public's external debt is decreasing gradually within the total external debt, they stated that the public intervention will gradually decrease for the sustainability of external debts. However, the stress test put forward points to greater unsustainability for external debt rather than public debt.

Milea (2018) reached the following conclusion in its analysis for Romania between 2006 to 2017. Since 2011, Romania has started to pay the intensive foreign loans it has received in the previous periods. This situation enabled external debt to reach a sustainable structure.

In their study with the quantile autoregression model for the period 1990q42010q4 for Romania, Boengiu et al. (2011) stated that external debt in Romania is sustainable at the 10 percent significance level. However, if macroeconomic stability is not achieved in the country, sustainability may be lost.

Moşteanu et al. (2010) descriptively analyzed the external public debt in Romania for the period 1993-2008. They stated that the ineffective use of foreign loans can cause a debt crisis. 
Zaman and Georgescu (2015) investigated the sustainability of external debt in Romania by descriptively evaluating various debt ratios for the period 2007-2013. Many indicators in terms of external indebtedness and debt service were close to unsustainable critical levels.

In their descriptive study for Romania for the period 2007-2011, Zaman and Vasile (2014) revealed that the external debt exceeds critical levels in Romania. Besides, they listed the factors that may affect external debt to increase the sustainability of external debt in the short-medium and long term. They stated that by comparing the situation of Romania with other countries, new threshold values in external debt indicators should be determined depending on the level of economic and social development of Romania.

Despotović and Durkalić (2017) stated with correlation analysis that debt grew in Albania and North Macedonia. The multi-criteria results also showed that, for 2014, North Macedonia was in a poor condition due to its high debt level. Other transitional economies such as Croatia, Slovenia and Bulgaria were countries with high debt. Because of high debt levels, according to the multiple criteria method, they were worse in 2014 rankings.

Considering the studies on the Transition Economies of Southeast Europe, the point that distinguishes this study from others is that not many studies in the literature examine external debt sustainability by applying unit root methods. Also, this study is the first to apply wavelet-based unit root tests to external debt sustainability.

\section{Theoretical background of external debt sustainability: Inter-temporal budget constraints approach}

The study of both internal public and external debt sustainability is structurally similar. Both structures are focused on the analysis of inter-temporal government budget constraints. Whereas the former rests on the public sector's funding constraint, which relates the primary deficit plus nominal debt servicing to adjustments in outstanding debt, the latter relates external debt to debt service and next exports. In particular, the following mechanism of accumulation of external debt is considered in period $t+1$, denoted by $B_{t+1}$

$$
\mathrm{B}_{\mathrm{t}+1}=(1+\mathrm{r}) \mathrm{B}_{\mathrm{t}}-\mathrm{NX}_{\mathrm{t}+1}
$$

Here $N X_{t+1}$ reflects net exports in period $\mathrm{t}+1, \mathrm{r}$ is the nominal interest rate, and $\mathrm{r} B_{t}$ is debt service in period $\mathrm{t}$ (Neaime and Gaysset, 2017).

Iterating equation (1) forward $n$ periods is obtained and the external intertemporal constraint of the government is summed up.

$$
B_{t}=\sum_{j=1}^{n} \frac{N X_{t+j}}{(1+r)^{j+1}}+\lim _{n \rightarrow \infty} \frac{B_{n}}{(1+r)^{n}}
$$


If the last term in equation 2 reaches zero as the number of periods increases, then equation 3 will satisfy the No-Ponzi-Game Constraint, also known in the literature as the transversality condition (Neaime and Gaysset, 2017).

$$
\lim _{n \rightarrow \infty} \frac{B_{n}}{(1+r)^{n}}=0
$$

The No-Ponzi-Game Constraint clearly states that if the country is solvent, the present value of potential external debt goes to zero in the long run. That is, a good Ponzi-game cannot be played by the country: the country is unable to pay interest on its unpaid external debt indefinitely simply by borrowing more. Solvency does not entail the redemption of the debt; only the indefinite funding of the interest bill by new borrowing is unlikely (Önal and Utkulu, 2006). External debt B in the numerator must rise more slowly than the interest rate $r$ for this to occur. By constantly issuing new external debt, the government cannot fund interest payments on the external debt. This will happen when equation 3 is not violated, and equation 2 reduces to:

$$
B_{t}=\sum_{j=1}^{n} \frac{N X_{t+j}}{(1+r)^{j+1}}
$$

For external debt sustainability, this is the solvency requirement that has to be met. Empirically, if the external debt variable is non-stationary, it suggests that it rises over time without being tied, implying that subsequent debt can also rise without making external debt unsustainable. In equation 3, this would also break the No-Ponzi-Game constraint. A stationary external debt variable means that the variables are reverting to certain mean overtime and do not extend without restrictions. If that were the case, the external debt would be sustainable because it would be under command (Neaime and Gaysset, 2017).

\section{Econometric methodology}

Determining the stochastic nature of a variable is important for several reasons. The first of these is to determine whether the effect of shocks is permanent or temporary. If the effect of a shock is permanent, that is, the deviations do not tend to return to the mean without intervention, effective policies on such variables can make the impact of the shocks temporary. On the other hand, if the effect of a shock is temporary, that is, the deviations tend to return to the mean without intervention, no intervention is required for such variables. This is because deviations tend to return to the average over time. Second, since variables may be in a relationship with another variable, the first step in investigating this relationship is to determine their stochastic structures. Third, future predictions regarding the variables have a very important place for politicians. If a variable is stationary, the impact of shocks is temporary; it is possible to make predictions values of such a variable. On the other hand, it is not 
possible to make future predictions for a non-stationary variable where the effects of shocks are permanent. Finally, it is very important to determine the stochastic structure of the variables in choosing the correct estimation method to be used. Analyses carried out without examining the stochastic structure of the variables may cause the use of wrong methods, thus obtaining biased results (Aydın and Aydın, 2020).

When the literature is examined, many studies on stationary variables are encountered. Some of these are ADF, PP, KPSS tests that disregard the structural breaks. Besides, Perron (1989) test, which regarded the structural breaks and determines these structural breaks externally, is available. There are many tests in the literature to determine structural breaks internally. The weakness of these tests is that the structure, form, and number of internally modeled structural breaks must be known in advance. To overcome this problem, Becker et al. (2004) and Becker et al. 2006) were able to perform unit root tests through Fourier terms and structural properties, without requiring any prior knowledge about breaks. Another advantage of such tests is that they allow soft breaks instead of hard breaks. Becker et al. (2006) 's Fourier KPSS test, Enders and Lee (2012a)' s Fourier LM test, Enders and Lee (2012b) 's Fourier DF test, and Rodrigues and Taylor (2012)' s Fourier GLS unit root tests are the main unit root tests using Fourier terms (Aydın and Aydın, 2020).

The wavelet-based unit root test typically employs the discrete wavelet transform in wavelet decomposition. In the discrete wavelet transform, the wavelet coefficients are as follows;

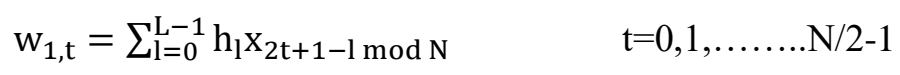

The scale coefficients are as follows for the discrete wavelet transform;

$$
\mathrm{v}_{1, \mathrm{t}}=\sum_{\mathrm{l}=0}^{\mathrm{L}-1} \mathrm{~g}_{\mathrm{l}} \mathrm{X}_{2 \mathrm{t}+1-\mathrm{l} \bmod \mathrm{N}} \quad \mathrm{t}=0,1, \ldots \ldots . . \mathrm{N} / 2-1
$$

The filters used are an important difference between the equations. The $h_{l}$ and $g_{l}$ filters are used for wavelet and scale coefficients, respectively. The wavelet-based unit root tests mentioned in the literature are performed using the linear data generation technique. However, there is no wavelet-based unit root test based on a nonlinear method of data generation in the literature. Aydin (2019) proposed a wavelet-based nonlinear unit root test based on Kapetanios, Shin, and Snell's (KSS) unit root methodology (Kapetanios et al., 2003) to fill this gap. Besides, the proposed test was extended to consider structural breaks.

Thus, the model used for the nonlinear wavelet-based unit root test is written as follows:

$$
\Delta \mathrm{V}_{1, \mathrm{t}}=\sum_{\mathrm{j}=1}^{\mathrm{p}} \mathrm{p}_{\mathrm{j}} \Delta \mathrm{V}_{1, \mathrm{t}-\mathrm{j}}+\delta \mathrm{V}_{1, \mathrm{t}-1}^{3}+\varepsilon_{\mathrm{t}}
$$


The KSS unit root test model with wavelet transform is given in Equation 7. The test statistics of the nonlinear wavelet-based KSS unit root test are as follows;

$$
\text { WKSS }=\widehat{\delta} / \text { s.h. }(\widehat{\delta})
$$

Here s.h. refers to the standard deviation. The presence of the unit root test is the basic hypothesis of the WKSS test and the alternative hypothesis has a stationary structure (Aydin, 2019).

Yazgan and Özkan (2015) used Fourier functions to identify structural breaks in wavelet transforms. They presented the data generation method to be used for the identification of structural breaks as follows;

$$
y_{t}=\mu(t)+\varepsilon_{t}
$$

Therefore, structural breaks of the regression coefficients in Equation 9 are defined by the following function;

$$
\mu(\mathrm{t}) \cong \alpha \sum_{\mathrm{i}=1}^{\mathrm{n}}\left\{(2 \mathrm{i}-1)^{-1} \sin \left[\frac{2 \pi(2 \mathrm{i}-1) \mathrm{kt}}{\mathrm{T}}\right]\right\}
$$

where $\mathrm{n}$ is the number of frequencies in the procedure, $\mathrm{k}$ symbolizes a certain frequency and $\alpha$ refers to sizes (amplitude). The break numbers and whether they are temporary or permanent are calculated by the frequency coefficient $\mathrm{k}$ alone. Also, when a single frequency is used $(n=1)$, the transitions tend to be smooth, while higher n-values allow the study of sudden temporary or permanent breaks. Aydin (2019) took the $n=1$ value for the Fourier WKSS (FWKSS) test and recommended the following model:

$$
\Delta \mathrm{V}_{1, \mathrm{t}}=\sum_{\mathrm{j}=1}^{\mathrm{p}} \mathrm{p}_{\mathrm{j}} \Delta \mathrm{V}_{1, \mathrm{t}-\mathrm{j}}+\delta \mathrm{V}_{1, \mathrm{t}-1}^{3}+\beta \sin (2 \pi \mathrm{kt} / \mathrm{T})+\varepsilon_{\mathrm{t}}
$$

where V1,t represents the scaling coefficients. Aydın (2019) suggests the following steps for the FWKSS test, taking into account Enders and Lee (2012b). In the first step, Equation 11 is predicted for the range $1 \leq \mathrm{k} \leq 5$. The model with the smallest sum of the squares of its residuals is chosen as the most suitable model. In the second step, nonlinearity is determined by the standard t-test. Also, since the classical critical values cannot be used in the case of unit root null hypotheses, new critical $\mathrm{t}(\widehat{\mathrm{k}})$ values were calculated by Aydin (2019, Table 5). By following Becker et al. (2004), Aydin (2019) has produced critical values. when the Fourier function is insignificant, the use of the WKSS unit root test method is proposed. 


\section{Data set and empirical findings}

The countries involved in the study, the data used, the source of the data and the time dimension of the data in the study are shown in Table 1. We use two variables to analyze sustainability. The first one is gross external debt (GED); the second one is GED/GDP. In the study, since the GDP series is in euro, but the gross external debt series is in dollars, the debt series are converted to euro to perform the analysis with GED/GDP. All series are in nominal values. GDP series were obtained from Eurostat. The data set is quarterly.

Not all Southeast European countries are selected in the analysis. The reason for choosing only some of the countries in the region is that these countries are transitional economies. Other transitional economies in this region not included in the analysis are Bosnia-Herzegovina, Serbia, Montenegro and Kosovo. Convenient data could not be reached for these countries. Additionally, some features of transitional economies are noteworthy and stated in the following parts.

The collapse of communism raised hopes that, as they transitioned to a capitalist economy, centrally planned economies would drive robust economic growth and eventually catch up to middle-income developing countries (Svejnar, 2002). External debt crises often occur in developing and transitional economies in tandem with currency crises. Inflows of short-term capital have poured into developing economies as they integrate into international capital markets, lured by high real interest rates and high investment yields. While foreign capital inflows have advantages, massive inflows of short-term capital trigger asset market bubbles, strengthen domestic currencies, reduce tradable sector international competitiveness, and increase current account deficits and external debt (Wang, 2004). Several transition countries began the 1990s with significant foreign debt. In 1990, Bulgaria's foreign debt approached 50\% of GDP. Other transformation economies, such as Romania and Slovenia, had conservative governments in 1990, with external debt of less than $20 \%$ of GDP. These disparities in starting conditions had a significant impact on these countries' subsequent results. Much of the heavily indebted countries had decreased their debt compared to GDP by the mid-1990s, while a few of the least indebted countries had increased theirs (Svejnar, 2002).

Table 1. Data set

\begin{tabular}{|c|c|c|c|}
\hline Countries & $\begin{array}{l}\text { Time Range of } \\
\text { GED Variable }\end{array}$ & GED Variable Source & $\begin{array}{l}\text { Time Range of } \\
\text { GED/GDP }\end{array}$ \\
\hline Albania & $\begin{array}{l}2006 \mathrm{q} 1-2020 \mathrm{q} 2 \\
\text { (58 Observations) }\end{array}$ & $\begin{array}{l}\text { Quarterly External Debt Statistics } \\
\text { GDDS }\end{array}$ & $\begin{array}{l}2008 \mathrm{q} 1-2020 \mathrm{q} 2 \\
\text { (50 Observations) }\end{array}$ \\
\hline Bulgaria & $\begin{array}{l}2005 q 3-2020 q 2 \\
\text { (60 Observations) }\end{array}$ & $\begin{array}{l}\text { Quarterly External Debt Statistics } \\
\text { SDDS }\end{array}$ & $\begin{array}{l}2005 \mathrm{q} 3-2020 \mathrm{q} 2 \\
(60 \text { Observations) }\end{array}$ \\
\hline Croatia & $\begin{array}{l}1999 \mathrm{q} 4-2020 \mathrm{q} 2 \\
(83 \text { Observations) }\end{array}$ & $\begin{array}{l}\text { Quarterly External Debt Statistics } \\
\text { SDDS }\end{array}$ & $\begin{array}{l}\text { 1999q4 - 2020q2 } \\
\text { (83 Observations) }\end{array}$ \\
\hline
\end{tabular}




\begin{tabular}{|c|c|c|c|c|c|}
\hline Romania & $\begin{array}{l}\text { 2008q2- 2020q2 } \\
\text { (49 Observations) }\end{array}$ & $\begin{array}{l}\text { Quarterly External } \\
\text { SDDS }\end{array}$ & Debt & Statistics & $\begin{array}{l}\text { 2008q2- 2020q2 } \\
\text { (49 Observations) }\end{array}$ \\
\hline Slovenia & $\begin{array}{l}2009 q 1-2020 q 2 \\
\text { (46 Observations) }\end{array}$ & $\begin{array}{l}\text { Quarterly External } \\
\text { SDDS }\end{array}$ & Debt & Statistics & $\begin{array}{l}2009 q 1-2020 q 2 \\
\text { (46 Observations) }\end{array}$ \\
\hline $\begin{array}{l}\text { North } \\
\text { Macedonia }\end{array}$ & $\begin{array}{l}2005 \mathrm{q} 4-2020 \mathrm{q} 2 \\
\text { (59 Observations) }\end{array}$ & $\begin{array}{l}\text { Quarterly External } \\
\text { SDDS }\end{array}$ & Debt & Statistics & $\begin{array}{l}2005 \mathrm{q} 4-2020 \mathrm{q} 2 \\
\text { (59 Observations) }\end{array}$ \\
\hline
\end{tabular}

Source: Author's calculations

By examining the stochastic structures of these variables, it is possible to determine the effects of shocks on variables. Therefore, wavelet-based unit root tests, in which frequency and time information are used together, were performed in the study. For this purpose, firstly, to determine the correct analysis method, whether the variables have a linear structure or not were examined with the BDS test. Table 2 shows the results of the linearity test.

Table 2. Linearity test results

\begin{tabular}{|c|c|c|c|c|c|}
\hline $\begin{array}{l}\text { Variable and } \\
\text { Country }\end{array}$ & Dimension & $\begin{array}{l}\text { BDS } \\
\text { Statistics }\end{array}$ & Standard Error & Z-Statistics & Prob. \\
\hline GED & 2 & 0.180641 & 0.007228 & 24.99318 & 0.0000 \\
\hline \multirow[t]{4}{*}{ Albania } & 3 & 0.318171 & 0.011558 & 27.52851 & 0.0000 \\
\hline & 4 & 0.406834 & 0.013845 & 29.38581 & 0.0000 \\
\hline & 5 & 0.470815 & 0.014515 & 32.43586 & 0.0000 \\
\hline & 6 & 0.512306 & 0.014082 & 36.37944 & 0.0000 \\
\hline \multirow{5}{*}{$\begin{array}{l}\text { GED } \\
\text { Bulgaria }\end{array}$} & 2 & 0.110067 & 0.005905 & 18.64076 & 0.0000 \\
\hline & 3 & 0.207989 & 0.009409 & 22.10489 & 0.0000 \\
\hline & 4 & 0.279093 & 0.011230 & 24.85326 & 0.0000 \\
\hline & 5 & 0.314908 & 0.011730 & 26.84657 & 0.0000 \\
\hline & 6 & 0.337675 & 0.011337 & 29.78490 & 0.0000 \\
\hline \multirow{5}{*}{$\begin{array}{l}\text { GED } \\
\text { Croatia }\end{array}$} & 2 & 0.191875 & 0.007728 & 24.82716 & 0.0000 \\
\hline & 3 & 0.325327 & 0.012382 & 26.27395 & 0.0000 \\
\hline & 4 & 0.416190 & 0.014861 & 28.00471 & 0.0000 \\
\hline & 5 & 0.475697 & 0.015612 & 30.47040 & 0.0000 \\
\hline & 6 & 0.511771 & 0.015174 & 33.72625 & 0.0000 \\
\hline \multirow{5}{*}{$\begin{array}{l}\text { GED } \\
\text { Romania }\end{array}$} & 2 & 0.128976 & 0.007252 & 17.78500 & 0.0000 \\
\hline & 3 & 0.219401 & 0.011731 & 18.70245 & 0.0000 \\
\hline & 4 & 0.276854 & 0.014215 & 19.47553 & 0.0000 \\
\hline & 5 & 0.313133 & 0.015079 & 20.76619 & 0.0000 \\
\hline & 6 & 0.320985 & 0.014803 & 21.68416 & 0.0000 \\
\hline \multirow{5}{*}{$\begin{array}{l}\text { GED } \\
\text { Slovenia }\end{array}$} & 2 & 0.196630 & 0.007623 & 25.79395 & 0.0000 \\
\hline & 3 & 0.336678 & 0.012174 & 27.65600 & 0.0000 \\
\hline & 4 & 0.434020 & 0.014564 & 29.80049 & 0.0000 \\
\hline & 5 & 0.500498 & 0.015250 & 32.81916 & 0.0000 \\
\hline & 6 & 0.542109 & 0.014775 & 36.69134 & 0.0000 \\
\hline \multirow{4}{*}{$\begin{array}{l}\text { GED } \\
\text { North Macedonia }\end{array}$} & 2 & 0.145968 & 0.006222 & 23.45813 & 0.0000 \\
\hline & 3 & 0.252559 & 0.010028 & 25.18617 & 0.0000 \\
\hline & 4 & 0.323304 & 0.012103 & 26.71208 & 0.0000 \\
\hline & 5 & 0.367714 & 0.012786 & 28.75964 & 0.0000 \\
\hline
\end{tabular}




\begin{tabular}{|c|c|c|c|c|c|}
\hline & 6 & 0.398180 & 0.012498 & 31.85978 & 0.0000 \\
\hline GED/GDP & 2 & 0.138573 & 0.008475 & 16.35126 & 0.0000 \\
\hline \multirow{4}{*}{ Albania } & 3 & 0.252554 & 0.013702 & 18.43207 & 0.0000 \\
\hline & 4 & 0.334452 & 0.016596 & 20.15212 & 0.0000 \\
\hline & 5 & 0.393555 & 0.017597 & 22.36425 & 0.0000 \\
\hline & 6 & 0.425323 & 0.017268 & 24.63029 & 0.0000 \\
\hline \multirow{5}{*}{$\begin{array}{l}\text { GED/GDP } \\
\text { Bulgaria }\end{array}$} & 2 & 0.065647 & 0.007429 & 8.837074 & 0.0000 \\
\hline & 3 & 0.095400 & 0.011944 & 7.987442 & 0.0000 \\
\hline & 4 & 0.094793 & 0.014385 & 6.589891 & 0.0000 \\
\hline & 5 & 0.109805 & 0.015163 & 7.241396 & 0.0000 \\
\hline & 6 & 0.126188 & 0.014791 & 8.531472 & 0.0000 \\
\hline \multirow{5}{*}{$\begin{array}{l}\text { GED/GDP } \\
\text { Croatia }\end{array}$} & 2 & 0.108387 & 0.005278 & 20.53405 & 0.0000 \\
\hline & 3 & 0.180194 & 0.008453 & 21.31796 & 0.0000 \\
\hline & 4 & 0.239528 & 0.010137 & 23.62889 & 0.0000 \\
\hline & 5 & 0.283377 & 0.010639 & 26.63583 & 0.0000 \\
\hline & 6 & 0.310015 & 0.010330 & 30.01045 & 0.0000 \\
\hline \multirow{5}{*}{$\begin{array}{l}\text { GED/GDP } \\
\text { Romania }\end{array}$} & 2 & 0.036667 & 0.011263 & 3.255533 & 0.0011 \\
\hline & 3 & 0.060338 & 0.018197 & 3.315859 & 0.0009 \\
\hline & 4 & 0.068917 & 0.022032 & 3.128094 & 0.0018 \\
\hline & 5 & 0.120049 & 0.023354 & 5.140406 & 0.0000 \\
\hline & 6 & 0.159346 & 0.022913 & 6.954504 & 0.0000 \\
\hline \multirow{5}{*}{$\begin{array}{l}\text { GED/GDP } \\
\text { Slovenia }\end{array}$} & 2 & 0.173579 & 0.009670 & 17.95031 & 0.0000 \\
\hline & 3 & 0.296006 & 0.015500 & 19.09717 & 0.0000 \\
\hline & 4 & 0.376669 & 0.018617 & 20.23305 & 0.0000 \\
\hline & 5 & 0.434265 & 0.019572 & 22.18772 & 0.0000 \\
\hline & 6 & 0.471459 & 0.019041 & 24.76055 & 0.0000 \\
\hline \multirow{5}{*}{$\begin{array}{l}\text { GED/GDP } \\
\text { North Macedonia }\end{array}$} & 2 & 0.082477 & 0.008389 & 9.832038 & 0.0000 \\
\hline & 3 & 0.158498 & 0.013491 & 11.74814 & 0.0000 \\
\hline & 4 & 0.223259 & 0.016255 & 13.73485 & 0.0000 \\
\hline & 5 & 0.278189 & 0.017143 & 16.22789 & 0.0000 \\
\hline & 6 & 0.307888 & 0.016730 & 18.40388 & 0.0000 \\
\hline
\end{tabular}

Source: Author's calculations

According to the linearity test results, all variables show a nonlinear structure. Accordingly, the stochastic properties of all variables should be examined by nonlinear unit root tests. In this case, FWKSS and WKSS tests were applied to the variables. The results of the test applied are given in Table 3 .

The Fourier term was not found significant for gross external debt variables in Slovenia and North Macedonia and GED/GDP variable in Albania, Romania, Slovenia, and North Macedonia. GED/GDP variable in Croatia T-Test Statistic $t(\widehat{k})$ seems significant but the Fourier term was not found significant. So we cannot take into account the FWKSS test results for Croatia's GED/GDP variable. According to the significant results of FWKSS test about gross external debt, the variables in Albania, Bulgaria, Croatia, and Romania are stationary. So, the gross external debts of these countries are sustainable. Depending on the results of FWKSS test about GED/GDP variables, only in Bulgaria's GED/GDP is significant and 
stationary. Therefore, according to both variables (GED and GED/GDP), external debt is sustainable in Bulgaria.

Table 3. Non-linear Unit Root Test Results

\begin{tabular}{|c|c|c|c|c|c|c|c|c|c|}
\hline \multirow{3}{*}{ Variables } & \multicolumn{6}{|c|}{ FWKSS TEST } & \multicolumn{3}{|c|}{ WKSS TEST } \\
\hline & \multirow[t]{2}{*}{$\begin{array}{l}\text { FWKSS } \\
\text { Test } \\
\text { Statistics }\end{array}$} & \multicolumn{3}{|c|}{$\begin{array}{l}\text { FWKSS Critical Values } \\
\text { Aydın }(2019 \text {, Table } 2) \\
\text { Time is } 50(T=50) \text { Critical Values }\end{array}$} & \multirow[t]{2}{*}{$\begin{array}{l}\text { T-Test } \\
\text { Statistic } \\
\qquad \mathbf{t}(\widehat{\mathbf{k}})\end{array}$} & \multirow[t]{2}{*}{$\mathbf{k}$} & \multirow[t]{2}{*}{$\mathbf{p}$} & \multirow[t]{2}{*}{$\begin{array}{l}\text { WKSS } \\
\text { Test } \\
\text { Statistics }\end{array}$} & \multirow[t]{2}{*}{$\mathbf{P}$} \\
\hline & & $\% 1$ & $\% 5$ & $\% 10$ & & & & & \\
\hline $\begin{array}{l}\text { GED } \\
\text { Albania } \\
(\text { Case 1) }\end{array}$ & $-2.338 * *$ & -2.53757 & -1.88082 & -1.58411 & $-2.486^{* *}$ & 3 & 8 & ------ & - \\
\hline $\begin{array}{l}\text { GED } \\
\text { Bulgaria } \\
(\text { Case 1) }\end{array}$ & $-3.492 *$ & -2.53757 & -1.88082 & -1.58411 & $-3.141 *$ & 3 & 8 & ------ & - \\
\hline $\begin{array}{l}\text { GED } \\
\text { Croatia } \\
\text { (Case 1) }\end{array}$ & $-2.433^{* *}$ & -2.46119 & -1.85630 & -1.56419 & $-2.055^{* * *}$ & 4 & 8 & ------ & - \\
\hline $\begin{array}{l}\text { GED } \\
\text { Romania } \\
\text { (Case 1) }\end{array}$ & $-2.224 * *$ & -2.68806 & -2.00453 & -1.67529 & $-3.094 *$ & 2 & 4 & ------ & - \\
\hline $\begin{array}{l}\text { GED } \\
\text { Slovenia } \\
\text { (Case 1) }\end{array}$ & 1.453 & -3.05052 & -2.29388 & -1.92532 & 2.362 & 1 & 3 & -0.199 & 0 \\
\hline $\begin{array}{l}\text { GED North } \\
\text { Macedonia } \\
(\text { Case 1) }\end{array}$ & 0.615 & -2.46119 & -1.85630 & -1.56419 & 1.302 & 4 & 8 & 1.208 & 0 \\
\hline $\begin{array}{l}\text { GED/GDP } \\
\text { Albania } \\
\text { (Case 1) }\end{array}$ & 1.067 & -3.05052 & -2.29388 & -1.92532 & 1.134 & 1 & 8 & -0.161 & 2 \\
\hline $\begin{array}{l}\text { GED/GDP } \\
\text { Bulgaria } \\
\text { (Case 1) }\end{array}$ & $-2.796^{*}$ & -2.53757 & -1.88082 & -1.58411 & $-1.927 * *$ & 3 & 8 & ------- & - \\
\hline $\begin{array}{l}\text { GED/GDP } \\
\text { Croatia } \\
\text { (Case 1) }\end{array}$ & -1.095 & -2.46119 & -1.85630 & -1.56419 & $-3.053 *$ & 4 & 6 & -0.913 & 2 \\
\hline $\begin{array}{l}\text { GED/GDP } \\
\text { Romania } \\
\text { (Case 1) }\end{array}$ & -0.728 & -3.05052 & -2.29388 & -1.92532 & 1.157 & 1 & 7 & $-2.924 *$ & 2 \\
\hline $\begin{array}{l}\text { GED/GDP } \\
\text { Slovenia } \\
\text { (Case 1) }\end{array}$ & 2.813 & -3.05052 & -2.29388 & -1.92532 & 3.205 & 1 & 8 & -0.463 & 4 \\
\hline $\begin{array}{l}\text { GED/GDP } \\
\text { North } \\
\text { Macedonia } \\
\text { (Case 1) }\end{array}$ & -0.655 & -2.53757 & -1.88082 & -1.58411 & 2.659 & 3 & 5 & 0.660 & 2 \\
\hline
\end{tabular}

Notes: Critical Values for WKSS test is $-2.43,-1.84$ and -1.57 at the $1 \%, 5 \%$ and $10 \%$ significance level, respectively. Critical values for FWKSS test t-statistics $t(\widehat{k})$ is -2.58 , 1.76 , and -1.34 at the $\% 1, \% 5$ and $\% 10$ significance level, respectively. Case 1 is raw data. $\mathrm{k}$ belongs to frequency and $\mathrm{p}$ belongs to lag length. *, ** and *** is significance level at the $\% 1, \% 5$ and $\% 10$, respectively.

Source: Author's calculations 
Due to the meaninglessness of the Fourier term, WKSS test was applied to other variables. Depending on the results of WKSS test of GED/GDP variable, this is stationary in Romania. Therefore, according to both variables (GED and GED/GDP), external debt is sustainable in Romania. According to the results of WKSS test about gross external debt variables in Slovenia and North Macedonia are non-stationary. So, the gross external debts of these countries are unsustainable. Concerning WKSS test results, the GED / GDP variables are non-stationary in Albania, Croatia, Slovenia, and North Macedonia.

As a result, it is seen that external debt in Romania and Bulgaria is sustainable. However, in North Macedonia and Slovenia, it is unsustainable. In terms of gross external debt, external debt is sustainable in Albania and Croatia. However, an unsustainable structure emerged in terms of the ratio of gross external debt to gross domestic product.

Considering the studies that clearly show whether the external debt in selected countries is sustainable or not, it is seen that some studies support our results in the literature section. Our results support Jošić's (2013) study for Croatia but the opposite for Bulgaria. Depending on the results of GED/GDP variable of Croatia, Gligorov (2004)'s study is also supported. Boengiu et al. (2011) and Emilia and Emilian's (2008) sustainability results for Romania also support the results of this study. Cuestas et al. (2015) is another study that supports our study as a result of unsustainable external debt for Slovenia.

The macroeconomic structure and debt status of the countries are important. At this point, the debt status of the countries considered can be summarized as follows. In other words, what are the reasons or situations that external debts are sustainable in some countries while not in others?

The evolution of the external debt and its components showed a turning point in 2013 and the foreign debt and its components started to decrease, a trend which continued for the total foreign debt in 2014 and 2015 in Romania. This decreasing trend occurred in 2015 for the short-term foreign debt and throughout 2013-2017, for the medium and long-term foreign debt. The growth of private non-guaranteed external debt slowed in 2009 and even reversed in subsequent years, owing to a lack of liquidity, reduced economic activity, and creditors' risk aversion, all of which were determined by the economic financial crisis and its consequences. As of 2009, the decline in the share of private non-guaranteed external debt was beneficial to the external debt's long-term sustainability. The National Bank of Romania's reserve assets have been steadily increasing, demonstrating Romania's financial-banking stability and credibility (Milea, 2018).

In terms of Bulgaria's external debt, the trend in recent years has been downward. The country has enough buffers in case of a rise in economic risks or a new crisis, thanks to low levels of public debt, a currency board structure, and foreign exchange reserves for its maintenance (Nikolova, 2019). 
When the Great Recession struck Slovenia in late 2008, most Slovenian banks became instantly illiquid. This was mostly due to their method of financing: rather than using deposit channels, the banks used international borrowing to fund their investments. As a result, between 2004 and 2008, Slovenia's net external debt increased from -3.4 percent to 30.9 percent of GDP. Slovenian banks reduced the amount of loans to domestic non-banking sectors as liabilities to foreign banks became due and refinancing options became limited. Slovenian businesses were severely harmed as a result of the country's de facto credit crunch. Liquidity strains were only offset at the end of 2011 by the use of non-standard steps by the European Central Bank, which included long-term funds with a three-year lifespan (Guardiancich, 2016).

Macedonia's core macroeconomic fundamentals strengthened in the run-up to the global financial crisis in 2008. Favorable external developments, as well as rising domestic demand resulted in lower total external and government debt, accumulation of foreign reserves, and a balanced fiscal policy. On the other hand, the consequences of the global recession on the Macedonian economy were more severe at the end of 2008 and proceeded into the first half of 2009 with a significant negative impact on foreign trade and capital inflows from abroad. Domestic absorption also declined substantially in 2009 as a result of the fall in trade and financial borrowing restrictions for domestic agents. In certain circumstances, government fiscal policy provided substantial economic relief throughout the recession years, but it also raised total external and public debt (Andonova and Stefanova, 2015).

Albania was shaken by two big shocks. On 26 November 2019, Albania was hit by a severe earthquake that killed 51 people and caused serious physical damage. In addition, the ongoing COVID-19 pandemic is seriously disrupting economic activity amid tightening global financial conditions in anticipation of sharp drops in tourism, foreign direct investment, remittances and temporarily restricted financing. Also, Albania's debt profile has undergone various changes. Over the last decade, the amount of external debt in gross public debt has risen from around 30\% in 2008 to around 47\% at the end of 2019. The ratio of external debt to GDP remains high. Most of the external debt continues to be held by multilateral creditors and bilateral development agencies. However, the share of commercial debt is expected to increase. Most of the external public debt is in euros, including intergovernmental loans and Eurobonds, and some IMF loans in terms of special drawing rights (IMF, 2020).

Due to high private consumption and exports of goods and services, Croatia's economy grew for the fourth year in a row in 2018 Wages are rising, unemployment is decreasing, and inflation is staying low. In the coming years, growth is expected to be moderate as the economy approaches its potential. While the current account is expected to decrease but remain excessive, there is an expectation that external debt will continue to decrease. Total external debt decreased in 2017, but at a slower rate. Growing intercompany credit for direct investment, which was broad-based across sectors, was largely responsible for the slowdown in external deleveraging. 
In 2017, the net international investment position (NIIP) fell to -62 percent of GDP, a significant improvement over 2009, when the NIIP was around -90 percent of GDP. The improvement was due to sustained current account surpluses, EU funds absorption, and GDP growth. NIIP fell to -53 percent of GDP as of 2018: 3rd Quarter. Therefore, the current pathway of NIIP does not imply risks for external sustainability or the need for a significant adjustment (IMF, 2019).

\section{Conclusions}

In this study, external debt sustainability in the transition economies of Southeast Europe, some of which are among the developing countries, is examined with wavelet-based unit root tests. To choose the correct test methodology, the variables were first tested in terms of linearity and it was found that all sustainability indicators had a non-linear structure. Therefore, FWKSS and WKSS unit root tests were applied to all these nonlinear variables. According to the results of the study, the external debt in Romania and Bulgaria is sustainable. However, in North Macedonia and Slovenia, it is unsustainable. In terms of gross external debt, external debt was sustainable in Albania and Croatia. However, an unsustainable structure emerged in terms of the ratio of gross external debt to gross domestic product.

For the gross external debt/GDP indicator to become fully sustainable, countries need to achieve their growth by transferring their foreign debt to investments. Therefore, the denominator part of this indicator will grow and sustainability will be achieved. In other words, countries should follow growthoriented policies. For this, these transition economy countries should attract foreign direct investment to their countries. In the context of growth-oriented policies, they will have to carry out structural reforms that will ensure the production of capitalintensive goods containing advanced technology in their industries. In addition to such growth-oriented policies, the implementation of realistic monetary, fiscal, and exchange rate policies and the improvement of foreign trade structure can reduce foreign trade deficits and limit the need for external debt.

In conclusion, in addition to the implementation of macroeconomic policies aimed at ensuring economic growth for sustainability, countries should decisively implement the principles of effective external debt management.

\section{References}

Aydın, M. (2019), A New Nonlinear Wavelet-based Unit Root Test with Structural Breaks, Munich Personal RePEc Archive Working Papers, No. 98693, Munich (retrieved from https://mpra.ub.uni-muenchen.de/98693/1/MPRA_paper_98693.pdf).

Aydın, M. and Aydın, M. (2020), Tarımsal emtia fiyatlarına gelen şokların etkisinin dalgacık tabanlı birim kök testleri ile incelenmesi, in: Toğuç, N. (ed.), Para ve finans, Adıyaman: İksad Publishing House, pp. 3-26. 
Babić, A., Krznar, I., Nestić, D. and Švaljek, S. (2005), Dynamic analysis of public and external debt sustainability, Croatian Economic Survey, (7), pp. 53-104.

Becker, R., Enders, W. and Hurn, S. (2004), A general test for time dependence in parameters, Journal of Applied Econometrics, 19(7), pp. 899-906.

Becker, R., Enders, W. and Lee, J. (2006), A stationarity test in the presence of an unknown number of smooth breaks, Journal of Time Series Analysis, 27(3), pp. 381-409. https://doi.org/10.1111/j.1467-9892.2006.00478.x

Boengiu, T., Triandafil, C.M. and Triandafil, A.M. (2011), Debt ceiling and external debt sustainability in Romania: A quantile autoregression model, Romanian Journal of Economic Forecasting, 4, pp. 15-29.

Cuestas, J.C., Gil-Alana, L.A. and Regis, P. J. (2015), The sustainability of European external debt: What have we learned?, Review of International Economics, 23(3), pp. 445-468. https://doi.org/10.1111/roie.12175

Despotović, D. and Durkalić, D. (2017), Analysis of budget deficit in the candidate countries for EU membership, Serbian Journal of Management, 12(2), pp. 237-253. https://doi.org/10.5937/sjm12-14122

Emilia, C. and Emilian, M. (2008), Analyzing the relationship between public and external debt sustainability: Case study Romania, International Conference Organized by University of Oradea, Faculty of Economics, Oradea, Romania, 21-23 November (retrieved from http://citeseerx.ist.psu.edu/viewdoc/similar?doi=10.1.1.497.3277\&type=sc).

Enache, C. (2010), External balance how vulnerable is Romania?, International Conference on Econophysics, New Economics and Complexity, Bucharest, Romania, 20-22 May (retrieved from https://www.researchgate.net/profile/Calcedonia_Enache/ publication/265099301_EXTERNAL_BALANCE_HOW_VULNERABLE_IS_RO MANIA/links/575b9bb908ae9a9c95519c91.pdf).

Enders, W. and Lee, J. (2012a), The flexible fourier form and dickey fuller type unit root tests, Economics Letters, 117(1), pp. 196-199. https://doi.org/10.1016/j.econlet.2012.04.081

Enders, W. and Lee, J. (2012b), A unit root test using a fourier series to approximate smooth breaks, Oxford Bulletin of Economics and Statistics, 74(4), pp. 574-599. https://doi.org/10.1111/j.1468-0084.2011.00662.x

Gligorov, V. (2004), Debt Sustainability and Growth in Croatia, Wiiw Research Reports, No.306, The Vienna Institute for International Economic Studies, Vienna (retrieved from https://wiiw.ac.at/debt-sustainability-and-growth-in-croatia-dlp-276.pdf).

Guardiancich, I. (2016), Slovenia: The end of a success story? When a partial reform equilibrium turns bad, Europe-Asia Studies, 68(2), pp. 205-231. https://doi.org/10.1080/09668136.2015.1126805

International Monetary Fund (2014), External Debt Statistics: Guide for Compilers and Users, IMF Publication Service (retrieved from http://tffs.org/pdf/edsg/ft2014.pdf).

International Monetary Fund (2019), Republic of Croatia: 2018 Article IV ConsultationPress Release; Staff Report; and Statement by the Executive Director for Republic of Croatia, IMF Country Report No. 19/46 (retrieved from 
https://www.imf.org/en/Publications/CR/Issues/2019/02/12/Republic-of-Croatia2018-Article-IV-Consultation-Press-Release-Staff-Report-and-Statement-by-46594). International Monetary Fund (2020), Albania: Request for Purchase under the Rapid Financing Instrument-Press Release; Staff Report; and Statement by the Executive Director for Albania, IMF Country Report No. 20/118 (retrieved from https://www.imf.org/en/Publications/CR/Issues/2020/04/17/Albania-Request-forPurchase-under-the-Rapid-Financing-Instrument-Press-Release-Staff-Report49347).

Jošić, H. (2013), Comparative analysis of external debt indicators in Croatia and SouthEastern European Countries, Ekonomska Misao I Praska, 22(1), pp. 197- 220.

Kapetanios, G., Shin, Y. and Snell, A. (2003), Testing for a unit root in the nonlinear STAR framework, Journal of Econometrics, 112(2), pp. 359-379. https://doi.org/10.1016/S0304-4076(02)00202-6

Krugman, P. (1988), Financing vs. forgiving a debt overhang, Journal of Development Economics, 29(3), pp. 253-268.

Man, M., Macris, M. and Ravas, B. (2013), The evolution of government debt internal and external to Romania in the current economic context generated by the economic crisis, International Journal of Management Sciences and Business Research, 2(2), pp. 110.

Milea, C. (2018), Romania's external debt: Trend and characteristics after the accession to the European Union, Financial Studies, 22(2), pp. 52-64.

Moşteanu, T., Postole, M.A. and Gherghina, R. (2010), The analysis of external and internal public debt in Romania, 11th International Conference Financial and Monetary Stability in Emerging Countries, Bucharest, Romania, 10-11 December (retrieved from http://store.ectap.ro/suplimente/Conferinta\%20FABBV\%202010_engleza.pdf).

Neaime, S. and Gaysset, I. (2017), Sustainability of macroeconomic policies in selected MENA countries: Post financial and debt crises, Research in International Business and Finance, (40), pp. 129-140.

Nikolova, I. (2019), External debt and debt crises in European Economies, "Bulgaria and Romania: Country Members of the EU, Part of the Global Economy" Conference organized by Economic Research Institute, Bulgarian Academy of Sciences and Institute for World Economy at the Romanian Academy, Sofia, Bulgaria (retrieved from https://papers.ssrn.com/sol3/papers.cfm?abstract_id=3777055).

Önel, G. and Utkulu, U. (2006), Modeling the long-run sustainability of Turkish external debt with structural changes, Economic Modelling, 23(4), pp. 669-682.

Perron, P. (1989), The great crash, the oil price shock, and the unit root hypothesis, Econometrica, 57(6), pp. 1361-1401.

Pitchford, J. (1995), The current account and foreign debt, London: Routledge.

Pivac, S. and Pečarić, M. (2010), Multivariate and multicriterial foreign debt analysis of the selected transition economies, Croatian Operational Research Review, 1(1), pp. 124135 . 
Rodrigues, P.M. and Taylor, A.M.R. (2012), The flexible fourier form and local generalised least squares de-trended unit root tests, Oxford Bulletin of Economics and Statistics, 74(5), pp. 736-759. https://doi.org/10.1111/j.1468-0084.2011.00665.x

Svejnar, J. (2002), Transition economies: Performance and challenges, Journal of Economic Perspectives, 16(1), pp. 3-28. https://doi.org/10.1257/0895330027058

Toskovic, J., Adzic, J., Popovic, S. and Markovic, J. (2016), Impact on globalization trend of movement of external debt in the Western Balkans, Annals-Economy Series, 2, pp. 41-47.

Unevska-Andonova, D. and Janevska-Stefanova, D. (2015), Transmission of External Shocks in Assessing Debt Sustainability, the Case of Macedonia, The National Bank of the Republic of North Macedonia Working Papers, No. 2015-04. North Macedonia (retrieved from http://www.nbrm.mk/WBStorage/Files/WebBuilder_Transmission_ external_shocks_assessing_debt_sustainability.pdf).

Vlahinić-Dizdarević, N., Buterin, V. and Žagar, A. (2006), The external debt sustainability in Southeast European countries: The analysis of debt indicators, Third International Conference of the School of Economics and Business ICES2006 From Transition to Sustainable Development: The Path to European Integration, Sarajevo, BosniaHerzegovina, 12-13 October (retrieved from https://bib.irb.hr/datoteka/283583. Vlahinic-Dizdarevic_et.al._Sarajevo_2006.pdf).

Wang, Y.K. (2004), Causes and prevention of external debt crisis, ESCAP Symposium on External Debt Management, Bangkok, Thailand, (retrieved from https://citeseerx.ist.psu.edu/viewdoc/download?doi=10.1.1.484.4852\&rep=rep1\&typ e=pdf).

World Bank (2011), Global Development Finance 2012: External Debt of Developing Countries, World Bank Publications (retrieved from https://openknowledge. worldbank.org/handle/10986/8132).

Yazgan, M.E. and Özkan, H. (2015), Detecting structural changes using wavelets, Finance Research Letters, 12, pp. 23-37. https://doi.org/10.1016/j.frl.2014.12.003

Zaman, G. and Georgescu, G. (2015), Current and long run challenges of Romania's external debt sustainability, Procedia Economics and Finance, 32, pp. 4-10. https://doi.org/10.1016/S2212-5671(15)01357-X

Zaman, G. and Vasile, V. (2014), Economic-financial and social vulnerabilities of Romania in the period 2013-2020, Procedia Economics and Finance, 15, pp. 4-18. https://doi.org/10.1016/S2212-5671(14)00439-0 